\title{
Use of Sawing Waste from Zeolitic Tuffs in the Manufacture of Ceramics
}

\author{
M. Pansini, ${ }^{1}$ R. de Gennaro, ${ }^{2}$ L. Parlato, ${ }^{3}$ M. de'Gennaro, ${ }^{3}$ A. Langella, ${ }^{4}$ A. Marocco, ${ }^{1}$ \\ P. Cappelletti, ${ }^{3}$ and M. Mercurio ${ }^{4}$ \\ ${ }^{1}$ Laboratorio Materiali, Dipartimento di Meccanica, Strutture, Ambiente e Territorio, Università di Cassino, \\ Via G. Di Biasio 43, 03043 Cassino, Italy \\ ${ }^{2}$ CISAG, Università Federico II, Via Mezzocannone 8, 80134 Napoli, Italy \\ ${ }^{3}$ Dipartimento di Scienze della Terra, Università Federico II, Via Mezzocannone 8, 80134 Napoli, Italy \\ ${ }^{4}$ Dipartimento di Studi Geologici e Ambientali, Università del Sannio, Via dei Mulini, 59/A, 82100 Benevento, Italy
}

Correspondence should be addressed to M. Pansini, pansini@unicas.it

Received 26 February 2010; Accepted 19 April 2010

Academic Editor: Luigi Nicolais

Copyright (C) 2010 M. Pansini et al. This is an open access article distributed under the Creative Commons Attribution License, which permits unrestricted use, distribution, and reproduction in any medium, provided the original work is properly cited.

\begin{abstract}
This paper investigates the thermal transformation of powders of volcanic tuffs that are used as building stones and aims at thermally transforming them into ceramics. The following positive indications concerning this thermal transformation were found: (1) the structural evolution which brings products similar to traditional ceramics, (2) the good ability to give rise to dense and compact final products, and (3) the good mechanical properties and the lovely appearance of the final products. Nevertheless, the high values of linear shrinkages recorded in this work seem to strongly hinder the thermal transformation of this powder-like waste into ceramics. However, mixing this by-product with other powder-like waste exhibiting higher-dimensional stability, such as those deriving from sawing of granites, appears proper.
\end{abstract}

\section{Introduction}

Many types of naturally occurring rocks such as tuffs, sandstones, limestones, granites, lavas, and marbles have been massively used since ancient times as building materials owing to their good technological properties and aesthetic features. In particular, tuffs, sandstones, and limestones are usually cut into prismatic blocks used as building stones, whereas granites, lavas, and marbles are manufactured as slabs used as floors or in largely different shapes for friezes and ornaments of the most various types [1-7]. The demand for such materials remains over the years steadily high [8].

Such high productions imply a serious environmental problem due to the formation of huge amounts of powderlike wastes related to cutting and polishing operations of such rocks. Just to have an idea of the involved amounts of wastes it should be remembered that only $25 \%-30 \%$ of the exploited material is the finished product whereas more than $50 \%$ of the wastes is represented by sewing and polishing muds. Since muds are considered wastes, they are required to be landfill disposed, thus representing a further production cost. Finally, the problem concerning the small grain size of this material that could favour the dispersion, of at least a small part of it, in the atmosphere should not be disregarded. Scientific literature reports scarce data concerning the recycling of these wastes. Some proposals for reuse in agriculture as soil amendments were advanced wherever leaching tests account for low amounts of heavy metals (from the blades of the saws) and hydrocarbons (from lubricating oils). Other possible recycles of such wastes are as filler in bituminous conglomerates or as raw material for the production of lightweight expanded aggregates $[9,10]$.

The aim of this paper, which will develop through a long-term study, is to verify the possibility of transforming these powder-like wastes from manufacturing of various geomaterials (tuffs, sandstones, limestones, granites, lavas, and marbles) into ceramics as replacing material for traditional clays. This goal appears likely to be fulfilled on the basis of several considerations. First of all, it is remarkable that some of these geomaterials (e.g., volcanic tuffs) exhibit chemical 
composition which does not largely differ from those of traditional clays $[11,12]$.

It is therefore possible to reproduce chemical compositions close to those of traditional clays by a proper combination of the due amounts of different materials. Also, the chemical compositions of the starting mixtures of waste geomaterials suitable to thermal transformation into ceramics may be further enhanced by adding proper amounts of minerals of little or no value for which no utilization is at the moment envisaged.

Thus this paper, which represents the starting point of such long-term study, intends to investigate the possibility of transforming powder-like waste of two volcanic tuffs, the Campanian Ignimbrite (hereafter Cab70) from Southern Italy and an Epiclastite (hereafter LacBen) from Sardinia (Italy), as replacing materials for traditional clays. These materials were chosen on the basis of some specific aspects such as the large resource availability for both deposits, exhibiting potential for practical applications along with the widespread use for the production of dimension stones which provides large amounts of wastes.

Finally, the chemical and mineralogical composition of these geomaterials may be considered representative of similar volcanic phillipsite and chabazite or clinoptilolitebearing deposits all over the world.

\section{Materials and Methods}

The sample of Campanian Ignimbrite used in this paper is a product traded by Italiana Zeoliti s. r. l. (PignetoModena) under the trade name Cab70, whereas the sample of Epiclastite (LacBen) comes from a deposit sited in Bortivuile (Sassari, Northern Sardinia). The Campanian Ignimbrite is the product of a huge eruption of the Campi Flegrei volcanic area (37,000 years b.p.). This trachytic pyroclastite is mainly constituted by scoriae and pumice set in a cineritic matrix. Two different lithofacies characterize this formation: a zeolite-bearing yellow one and a grey one, with epigenetic feldspars. The zeolite amount, generally close to $50 \%$, in some deposits can even reach about 80\% [13-15].

The Sardinian samples (LacBen) belong to a volcanosedimentary succession generally resting on the Palaeozoic basement and linked to a calc-alkaline eruptive activity, oligo-aquitanian in age. The circulation of hydrothermal fluids through a faults system caused the transformation of the rhyolitic glassy fraction of epiclastic and unwelded pyroclastic deposits in clinoptilolite, smectite, and opal-CT $[16,17]$.

Bulk chemical analyses (ten major and nine trace elements) were performed by X-Ray Fluorescence (XRF, Philips PW1400, Centro Interdipartimentale di Servizio per analisi Geomineralogiche). Analytical procedures were carried out according to Melluso et al. [18]. Mineralogy was investigated by X-Ray Powder Diffraction (XRPD) with a Philips PW $1730 / 3710$ diffractometer $(\mathrm{CuK} \alpha$ radiation, $40 \mathrm{kV}, 30 \mathrm{~mA}$, curved graphite monochromator, scanning interval $3-80^{\circ}$, step size $=0.020^{\circ} 2 \theta$, counting time $5 \mathrm{~s}$ per step), on micronized aliquots of about $1 \mathrm{gr}$ for each sample. The quantitative mineralogical composition of these materials was carried out through the Reference Intensity Ratio (RIR) technique using $\alpha-\mathrm{Al}_{2} \mathrm{O}_{3}$ as internal standard [19].

The Cab70 and LacBen grain size distribution is determined by loading $100 \mathrm{~g}$ of each material from the top of a pile of sieves having openings of decreasing dimensions from top to bottom $(0.500,0.250,0.125$, and $0.063 \mathrm{~mm})$. After the pile of sieves is mechanically shaken for one minute, the amount of powder passing through each sieve is carefully weighed. Such values are reported as a function of the opening of the sieve.

Differential thermal analysis (DTA) and thermogravimetric analysis (TG) of Cab70 and LacBen samples are performed in air up to $1000^{\circ} \mathrm{C}$ using a Netzsch STA 409 (Centro Interdipartimentale di Servizio per analisi Geomineralogiche) multiple thermoanalyzer at $10^{\circ} \mathrm{C} / \mathrm{min}$ heating rate.

Cylindrical compacts are manufactured by putting the due amount of Cab70 and LacBen powders in cylindrical moulds and by pressing it at $39.2 \mathrm{MPa}$ with a uniaxial press. Different groups of compacts are obtained. The first two groups, which are manufactured using original, thermally untreated, Cab70 and LacBen powders, have the same diameter $d(4.05 \mathrm{~cm})$ but different heights $h(1.00,3.00 \mathrm{~cm})$. Other groups of cylindrical compacts are manufactured using previously thermally treated Cab70 and LacBen samples. Actually, $200 \mathrm{~g}$ of each of these powders were subjected to the following thermal cycle using platinum vessels and a Lenton furnace which ensures stable temperature to within $\pm 2^{\circ} \mathrm{C}$.

(1) They are heated up to a selected temperature at $10^{\circ} \mathrm{C} / \mathrm{min}$ heating rate.

(2) They are kept at this temperature $\left(600^{\circ} \mathrm{C}\right.$ for $\mathrm{Cab} 70$ and $800^{\circ} \mathrm{C}$ for LacBen) for 3 hours.

(3) After such time was elapsed, the furnace was switched off and the powders were left in the furnace until they cooled down to room temperature (this cooling procedure will be labelled from this point onwards as F).

These thermally treated materials were used to manufacture a third group of cylindrical compacts having $d$ $=4.05 \mathrm{~cm}$ and $h=1.00 \mathrm{~cm}$ according to the procedure previously described. Moreover, proper amounts of thermally treated materials were mixed with equal weights of original, thermally untreated, Cab70 and LacBen powders, and these mixtures were used to manufacture a fourth group of cylindrical compacts having $d=4.05 \mathrm{~cm}$ and $h=1.00 \mathrm{~cm}$ according to the procedure previously described.

All these compacts, together with Cab70 and LacBen powders, were subjected to various thermal treatments, summarised in Table 1, using the same platinum vessels and Lenton furnace previously described.

The products obtained by thermally treating powder-like Cab70 and LacBen were characterized by room temperature $\mathrm{X}$-ray diffraction. The products obtained by thermally treating the various compacts were characterized as follows.

(1) First is by room temperature X-ray diffraction (compacts manufactured according to thermal treatments summarised in Table 1b). 
TABLE 1: Synoptic table of performed thermal treatments.

\begin{tabular}{|c|c|c|c|c|c|c|c|c|c|c|c|}
\hline & $1 \mathrm{a}$ & $1 \mathrm{~b}$ & $1 \mathrm{c}$ & $1 \mathrm{~d}$ & $1 \mathrm{e}$ & If & $1 \mathrm{~g}$ & $1 \mathrm{~h}$ & $1 \mathrm{i}$ & 11 & $1 \mathrm{~m}$ \\
\hline Powder & $\begin{array}{l}\text { Cab70/ } \\
\text { LacBen }\end{array}$ & $\begin{array}{l}\text { Cab70/ } \\
\text { LacBen }\end{array}$ & $\begin{array}{l}\text { Cab70/ } \\
\text { LacBen }\end{array}$ & Cab70 & LacBen & Cab70 & LacBen & Cab70 & LacBen & Cab70 & LacBen \\
\hline Compact & No & Yes & Yes & Yes & Yes & Yes & Yes & Yes & Yes & Yes & Yes \\
\hline $\begin{array}{l}\text { Dimensions } \\
\text { of compacts, } \\
\mathrm{cm}\end{array}$ & - & $\begin{array}{l}d=4.05 \\
h=1.00\end{array}$ & $\begin{aligned} d & =4.05 \\
h & =1.00\end{aligned}$ & $\begin{array}{l}d=4.05 \\
h=1.00\end{array}$ & $\begin{aligned} d & =4.05 \\
h & =1.00\end{aligned}$ & $\begin{aligned} d & =4.05 \\
h & =3.00\end{aligned}$ & $\begin{aligned} d & =4.05 \\
h & =3.00\end{aligned}$ & $\begin{array}{l}d=4.05 \\
h=1.00\end{array}$ & $\begin{aligned} d & =4.05 \\
h & =1.00\end{aligned}$ & $\begin{array}{l}d=4.05 \\
h=1.00\end{array}$ & $\begin{aligned} d & =4.05, \\
h & =1.00\end{aligned}$ \\
\hline $\begin{array}{l}\text { Thermal } \\
\text { pretreat- } \\
\text { ment of } \\
\text { powders }\end{array}$ & No & No & No & No & No & No & No & Yes $^{\mathrm{a}}$ & Yes $^{b}$ & Mixed $^{c}$ & Mixed $^{\mathrm{d}}$ \\
\hline $\begin{array}{l}\text { Heating rate, } \\
{ }^{\circ} \mathrm{C} / \mathrm{min}\end{array}$ & 10 & 10 & 5 & 2 & 2 & 2 & 2 & 2 & 2 & 2 & 2 \\
\hline $\mathrm{T},{ }^{\circ} \mathrm{C}$ & $\begin{array}{c}500,600 \\
700,800 \\
900 \\
1000 \\
1100 \\
1200\end{array}$ & $\begin{array}{c}500,600 \\
700,800 \\
900,1000 \\
1200\end{array}$ & 1050 & 1050 & 1100 & 1050 & 1100 & 1050 & 1100 & 1050 & 1100 \\
\hline $\begin{array}{l}\text { Heating } \\
\text { time, hr }\end{array}$ & 3 & 5 & 5 & 5 & 5 & 5 & 5 & 5 & 5 & 5 & 5 \\
\hline $\begin{array}{l}\text { Cooling rate, } \\
{ }^{\circ} \mathrm{C} / \mathrm{min}\end{array}$ & $\mathrm{E}^{\mathrm{e}}$ & $\mathrm{E}^{\mathrm{e}}$ & $\mathrm{F}^{\mathrm{f}} / \mathrm{E}^{\mathrm{e}}$ & $\mathrm{G}^{\mathrm{g}} / \mathrm{E}^{\mathrm{e}}$ & $\mathrm{H}^{\mathrm{h}} / \mathrm{E}^{\mathrm{e}}$ & $\mathrm{G}^{\mathrm{g}} / \mathrm{Ee}$ & $\mathrm{H}^{\mathrm{h}} / \mathrm{E}^{\mathrm{e}}$ & $\mathrm{G}^{\mathrm{g}} / \mathrm{E}^{\mathrm{e}}$ & $\mathrm{H}^{\mathrm{h}} / \mathrm{E}^{\mathrm{e}}$ & $\mathrm{G}^{\mathrm{g}} / \mathrm{E}^{\mathrm{e}}$ & $\mathrm{H}^{\mathrm{h}} / \mathrm{E}^{\mathrm{e}}$ \\
\hline
\end{tabular}

a Yes: Thermal pretreatment at $600^{\circ} \mathrm{C}$ for 3 hours.

b Yes: Thermal pretreatment at $800^{\circ} \mathrm{C}$ for 3 hours.

${ }^{c}$ Mixed: $50 \%$ of untreated powder and $50 \%$ pre-heated at $600^{\circ} \mathrm{C}$ for 3 hours.

d Mixed: $50 \%$ of untreated powder and $50 \%$ pre-heated at $800^{\circ} \mathrm{C}$ for 3 hours.

${ }^{\mathrm{e}} \mathrm{E}$ Means that the furnace was switched off and the products were left in the furnace until they cooled down to room temperature $\left(25^{\circ} \mathrm{C}\right)$.

${ }^{f} \mathrm{~F}$ From $1050^{\circ} \mathrm{C}$ to $800^{\circ} \mathrm{C}$ the cooling rate is $5^{\circ} \mathrm{C} / \mathrm{min}$.

g G From $1050^{\circ} \mathrm{C}$ to $700^{\circ} \mathrm{C}$ the cooling rate is $2^{\circ} \mathrm{C} / \mathrm{min}$.

${ }^{\text {h }} \mathrm{H}$ From $1100^{\circ} \mathrm{C}$ to $700^{\circ} \mathrm{C}$ the cooling rate is $2^{\circ} \mathrm{C} / \mathrm{min}$.

(2) Second is by determining the weight loss and linear shrinkage of all the compacts.

(3) Third is by determining the porosity according to ASTM C373-88 (2005) regulation (compacts manufactured according to thermal treatments summarised in Table 1f and $1 \mathrm{~g}$ ). This regulation recommends measuring the weight of the fired product in air $\left(\mathrm{W}_{1}\right)$, the weight of the water-saturated fired product immersed in water $\left(\mathrm{W}_{2}\right)$, and the weight of the water-saturated fired product in $\operatorname{air}\left(\mathrm{W}_{3}\right)$. If $\mathrm{V}$ is the geometric volume of the fired product and the specific gravity of water is considered equal to unity, the following quantities may be defined:

(i) bulk density, $d_{b}=\mathrm{W}_{1} / \mathrm{V}$,

(ii) apparent density, $d_{a}=\mathrm{W}_{1} /\left(\mathrm{W}_{1}-\mathrm{W}_{2}\right)$,

(iii) percent porosity, $p=\left(\mathrm{W}_{3}-\mathrm{W}_{1}\right) 100 / \mathrm{V}$.

The porosity determinations were performed on three different compacts manufactured with Cab70 according to thermal treatment summarised in Table if and on four different compacts manufactured with LacBen according to thermal treatment summarised in Table $1 \mathrm{~g}$.
(4) Fourth is by scanning electron microscopy using a Philips XL30 apparatus (compacts manufactured according to thermal treatments summarised in Table $1 \mathrm{f}$ and $\mathrm{g}$ ).

(5) Fifth is by determining compressive strength, using a Belladonna electrohydraulic press equipped with a model TC8-TM $300 \mathrm{KN}$ AEP load cell $( \pm 0.1 \mathrm{KN})$ and Rockwell hardness, using a NR3 DSR Ernst hardness tester. The surface microhardness was determined on ceramic compacts by using a steel ball indenter with a $1.5875 \mathrm{~mm}$ diameter and a loading pressure of $30 \mathrm{KP}$ equal to $294 \mathrm{~N}$. Each of the measured values is followed by HR30T where HR stands for Hardness Rockwell, 30 is the pressure, and $T$ is the kind of indenter (compacts manufactured according to thermal treatments summarised in Table if and $1 \mathrm{~g})$. Reported values of compressive strengths and Rockwell hardness are the average of four and six determinations, respectively. Moreover, the values of Rockwell hardness of compacts are compared with the hardness (average of six determinations) of $110 \times 55 \times 5 \mathrm{~mm}$ tiles made up by a commercial stoneware used as a standard. Such commercial stoneware was manufactured by firing for 51 minutes at $1180^{\circ} \mathrm{C}$ a mixture of DBY3 clay (20 weight \%), 
TABle 2: Chemical composition of Cab70 and LacBen (wt. \%, XRFS).

\begin{tabular}{lcc}
\hline & Cab70 & LacBen \\
\hline $\mathrm{SiO}_{2}$ & 53.71 & 65.63 \\
$\mathrm{TiO}_{2}$ & 0.04 & 0.20 \\
$\mathrm{Al}_{2} \mathrm{O}_{3}$ & 16.10 & 13.50 \\
$\mathrm{Fe}_{2} \mathrm{O}_{3}$ & 4.01 & 1.06 \\
$\mathrm{MnO}$ & 0.02 & 0.01 \\
$\mathrm{MgO}$ & 1.01 & 1.04 \\
$\mathrm{CaO}$ & 4.01 & 2.49 \\
$\mathrm{Na}$ & 2.06 & 2.46 \\
$\mathrm{~K}_{2} \mathrm{O}$ & 7.03 & 1.11 \\
$\mathrm{P}_{2} \mathrm{O}_{5}$ & 0.01 & tr. \\
$\mathrm{LOI}$ & 12.00 & 12.50 \\
\hline
\end{tabular}

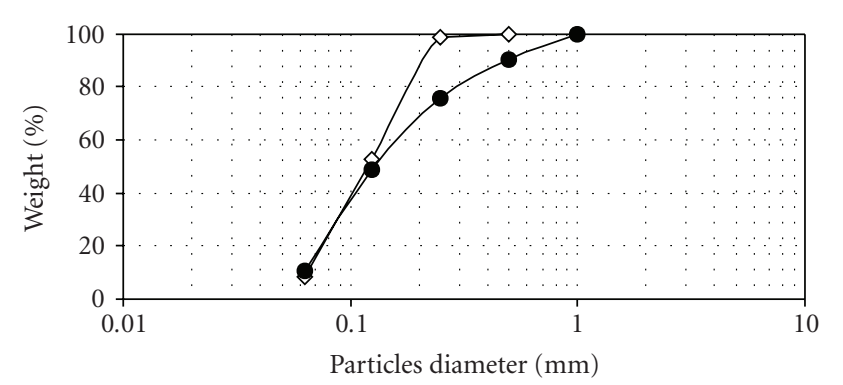

$\diamond$ Cab70

- LacBen

FIGURE 1: Grain size distribution curves of Cab70 and LacBen.

W2 clay (weight 20\%), quartz sand (15 weight \%), aplite (10 weight \%), L11 albite (25 weight \%), and S pegmatite (10 weight \%).

\section{Results}

The chemical compositions reported in Table 2 evidence the alkali-trachytic affinity of Cab70, [13] typical of volcanic products linked to the activity of Campi Flegrei and the rhyolitic one of LacBen characteristic of oligomiocene volcaniclastic activity of Northern Sardinia [17]. The mineralogical composition (Table 3 ) is characterized in both materials by the presence of zeolites such as phillipsite, chabazite, and analcime in Cab70 and clinoptilolite in LacBen, as a consequence of the different composition of the glassy precursor.

The grain size distribution curves of Cab70 and LacBen samples are reported in Figure 1 [20]. As far as Cab70 is considered, with the only exception of a very low amount (1\%) of fine sand, most of this sample is almost equally distributed between the very fine sand class (46\%) and the silt+clay class (53\%). Quite different was the grain size distribution of LacBen sample, mainly if the coarser grain size is concerned which distributes between the medium size sand $(10 \%)$, the fine sand (14\%), and very fine sand $(27 \%)$.
The remaining portion is made up of the subtle silt-clay fraction $(49 \%)$.

Figure 2 reports the most meaningful XRD patterns of Cab70 and LacBen [20]. The comparison between the patterns of untreated and thermally treated powders made it possible to detect the modifications involving the main phases as a function of temperature. As far as Cab70 is concerned, raising the temperature of the treatment results in the framework collapse of low thermal stability phases. The presence of phillipsite can be detected at temperatures not higher than $500^{\circ} \mathrm{C}$, whereas the presence of chabazite and analcime is recorded up to $700^{\circ} \mathrm{C}$. Actually, only the presence of feldspar and augite can be detected in the sample treated at $1100^{\circ} \mathrm{C}$. Thermally treating at $1200^{\circ} \mathrm{C}$ Cab70 results in its complete melting. The resulting material is totally amorphous as recorded by its XRD pattern.

As far as LacBen is concerned, thermal treatments evidence a low thermal stability of clinoptilolite that progressively disappears up to $700^{\circ} \mathrm{C}$. Higher temperatures only preserve small amounts of crystalline quartz, cristobalite, and feldspar dispersed in an amorphous matrix.

These behaviours, which are in good agreement with thermal transformations evidenced by previous experiments on both materials [21-26], were recorded in all the manufactured compacts.

The DTA and TG curves of Cab70 and LacBen samples are reported in Figure 3. As far as Cab70 sample is concerned, two main endothermic peaks may be recorded at 160 and $740^{\circ} \mathrm{C}$, and the total weight loss is about $12.0 \%$. It is remarkable that the TG curve of Cab70 sample exhibits a sort of evident step of about $1 \%$ magnitude at about $760^{\circ} \mathrm{C}$ in correspondence with the second endothermic peak, likely due to dehydroxilation of smectite (see Table 3 ). As far as LacBen sample is concerned, two main endothermic peaks may be recorded at 155 and $240^{\circ} \mathrm{C}$, and the total weight loss is about $12.5 \%$.

Table 4 reports the values of linear shrinkage and weight loss recorded after performing the thermal treatments of various compacts, summarized in Table $1 \mathrm{~b}, 1 \mathrm{c}, 1 \mathrm{~d}, 1 \mathrm{e}, 1 \mathrm{f}, 1 \mathrm{~g}$, $1 \mathrm{~h}, 1 \mathrm{i}, 1 \mathrm{l}$, and $1 \mathrm{~m}$.

As far as the thermal treatments summarised in Table $1 \mathrm{~b}$ are concerned, it was found that thermal treatments in the range $800-1000^{\circ} \mathrm{C}$ were able to evolve most of the water present in the system. In this same temperature range of thermal treatments moderate linear shrinkages (up to 5.5\%) were recorded, the exception being the compact manufactured with LacBen thermally treated at $1000^{\circ} \mathrm{C}(15.9 \%)$. The careful observation of the products of thermal treatments at temperatures not higher than $1000^{\circ} \mathrm{C}$ evidenced that such products lost some powder, which is indicative of poor sintering. This finding could explain the mass variation higher than those recorded in the TG analysis. Moreover, such products presented some fractures parallel to the axe of the cylindrical compacts, sited along their lateral surface. As far as thermal treatment at $1200^{\circ} \mathrm{C}$ (Table $1 \mathrm{~b}$ ) is concerned, compacts were found to undergo melting.

On the basis of these results the experimental conditions of subsequent thermal treatments were modified. Actually, the heating and cooling rates as well as the temperature 
TABLE 3: Mineralogical composition of Cab70 and LacBen (wt. \%, XRPD).

\begin{tabular}{|c|c|c|c|c|c|c|c|}
\hline Cab70 & & & & & & & \\
\hline Phillipsite & K-feldspar & Chabazite & Analcime & Smectite & Augite & Mica & Glass \\
\hline $43 \pm 2$ & $25 \pm 3$ & $5 \pm 1$ & $7 \pm 1$ & $12 \pm 1$ & tr. & tr. & $8 \pm 6$ \\
\hline \multicolumn{8}{|l|}{ LacBen } \\
\hline Clinoptilolite & Feldspar & Quartz & Opal & Mica & & & \\
\hline $66 \pm 1$ & $18 \pm 1$ & $3 \pm 1$ & $13 \pm 1$ & tr. & & & \\
\hline
\end{tabular}

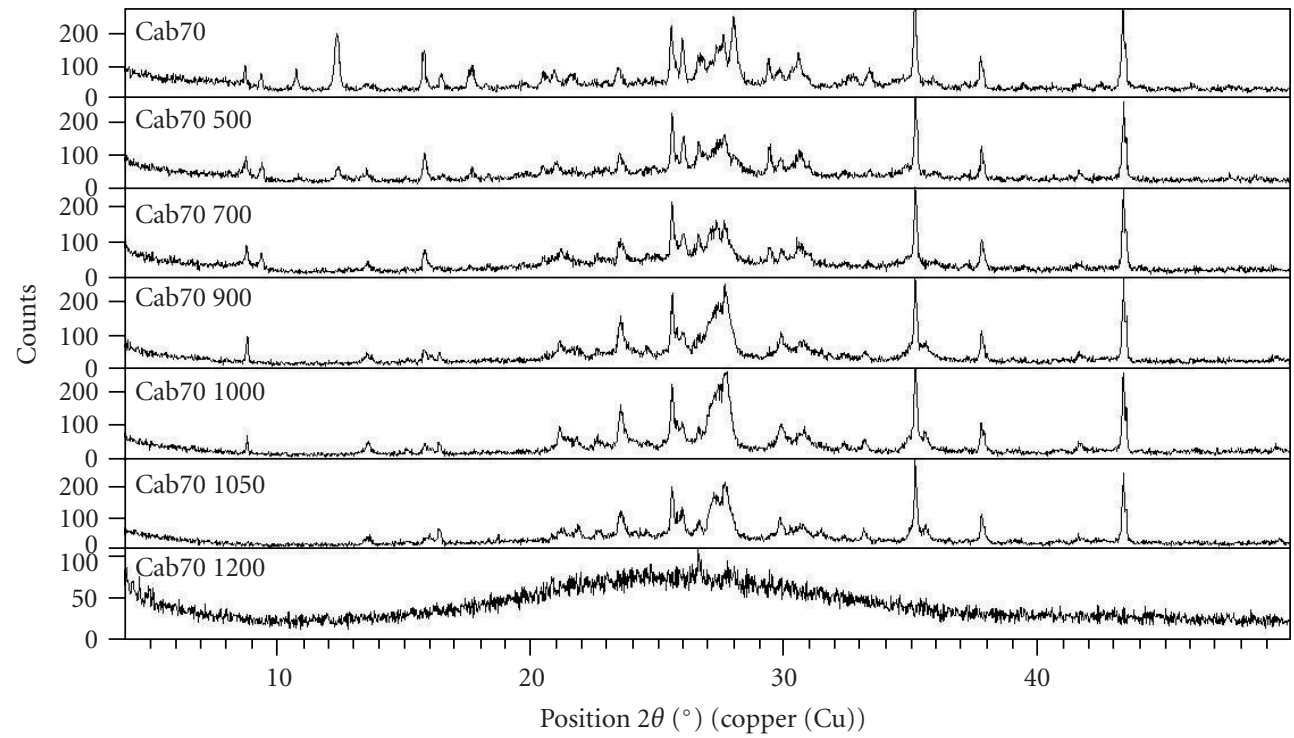

(a)

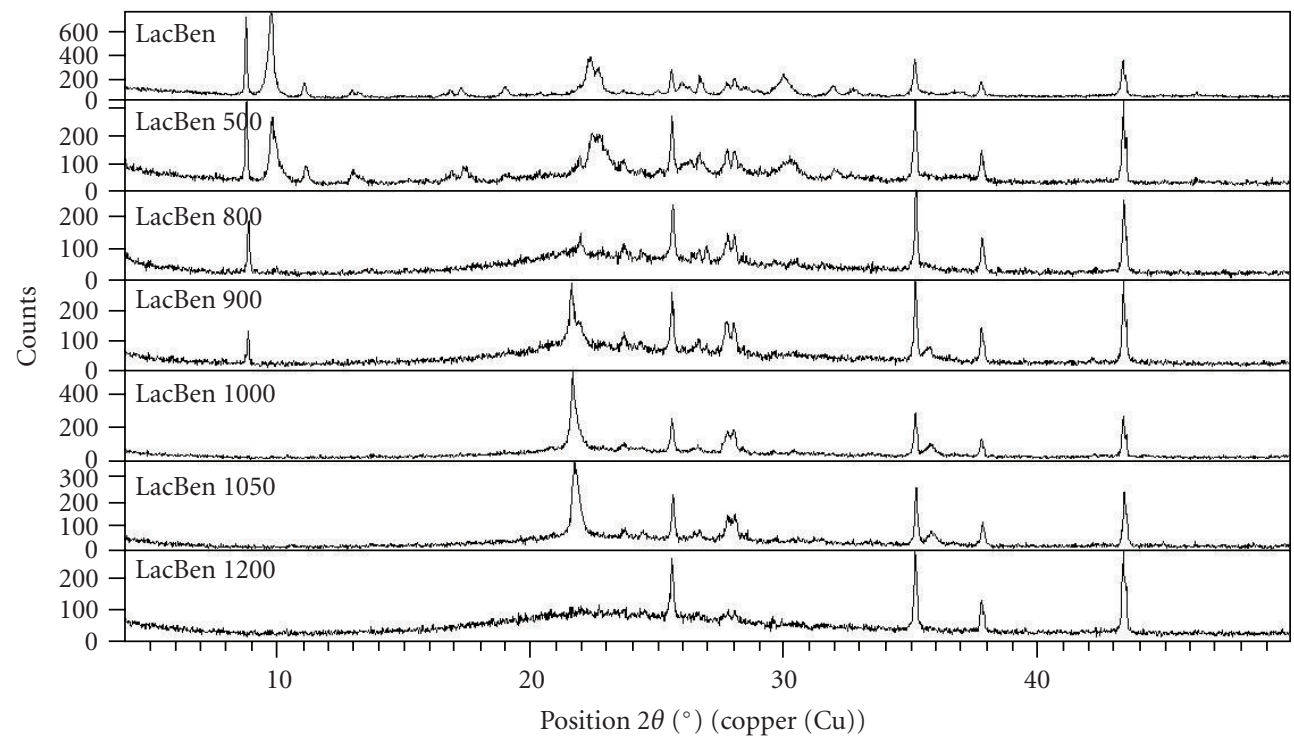

(b)

FIgURE 2: X-ray diffraction patterns of untreated and thermally treated Cab70 and LacBen powders for 5 hours at 500, 700, 800, 900, 1000, 1050 , and $1200^{\circ} \mathrm{C}$. 
TABle 4: Weight loss $(\Delta m \%)$ and linear shrinkage $(\Delta d \%)$ of compacts arising from various thermal treatments.

(a) Thermal treatments summarised in Table $1 \mathrm{~b}$

\begin{tabular}{lcccc}
\hline & \multicolumn{2}{c}{ Cab70 } & \multicolumn{2}{c}{ LacBen } \\
$T\left({ }^{\circ} \mathrm{C}\right)$ & $\Delta m \%$ & $\Delta d \%$ & $\Delta m \%$ & $\Delta d \%$ \\
\hline 500 & 8.2 & 0.4 & 8.8 & 1.8 \\
700 & 11.4 & 1.3 & 11.5 & 3.2 \\
800 & 12.7 & 2.8 & 13.9 & 3.5 \\
900 & 12.8 & 3.9 & 14.2 & 4.7 \\
1000 & 14.9 & 5.5 & 14.5 & 15.9 \\
1200 & melting & - & melting & - \\
\hline
\end{tabular}

(b) Thermal treatments summarised in Table 1c

\begin{tabular}{lcccc}
\hline & \multicolumn{2}{c}{ Cab70 } & \multicolumn{2}{c}{ LacBen } \\
$T\left({ }^{\circ} \mathrm{C}\right)$ & $\Delta m \%$ & $\Delta d \%$ & $\Delta m \%$ & $\Delta d \%$ \\
\hline 1050 & 13.0 & 25.3 & 14.5 & 25.5 \\
\hline
\end{tabular}

(c) Thermal treatments summarised in Table $1 \mathrm{~d}$ and $1 \mathrm{e}$

\begin{tabular}{lcccc}
\hline & \multicolumn{2}{c}{ Cab70 } & \multicolumn{2}{c}{ LacBen } \\
$T\left({ }^{\circ} \mathrm{C}\right)$ & $\Delta m \%$ & $\Delta d \%$ & $\Delta m \%$ & $\Delta d \%$ \\
\hline 1050 (see Table 3d) & 12.9 & 25.7 & & \\
1100 (see Table 3e) & \multicolumn{2}{c}{ partial melting } & 14.3 & 24.7 \\
\hline
\end{tabular}

(d) Thermal treatments summarised in Table $1 \mathrm{f}$ and $1 \mathrm{~g}(h=3 \mathrm{~cm})$

\begin{tabular}{lcccc}
\hline & \multicolumn{2}{c}{ Cab70 } & \multicolumn{2}{c}{ LacBen } \\
$T\left({ }^{\circ} \mathrm{C}\right)$ & $\Delta m \%$ & $\Delta d \%$ & $\Delta m \%$ & $\Delta d \%$ \\
\hline 1050 (see Table 3f) & 13.0 & 17.5 & & \\
1100 (see Table 3g) & & & 14.6 & 19.2 \\
\hline
\end{tabular}

(e) Thermal treatments summarised in Table $1 \mathrm{~h}, 1 \mathrm{i}, 1 \mathrm{l}$ and $1 \mathrm{~m}$

\begin{tabular}{lcccc}
\hline & \multicolumn{2}{c}{ Cab70 } & \multicolumn{2}{c}{ LacBen } \\
$T\left({ }^{\circ} \mathrm{C}\right)$ & $\Delta m \%$ & $\Delta d \%$ & $\Delta m \%$ & $\Delta d \%$ \\
\hline 1050 (see Table 3h) & 4.9 & 16.2 & & \\
1100 (see Table 3i) & & & 2.3 & 16.9 \\
1050 (see Table 31) & 9.0 & 16.7 & & \\
1100 (see Table 3m) & & & 6.0 & 17.4 \\
\hline
\end{tabular}

of the thermal treatment were reduced according to what is reported in Table 1c. The products of this thermal treatment were still characterised by the occurrence of the previously described fractures, although to a lower extent. Moreover, the thermal treatment summarised in Table 1c resulted in good sintering of the compact manufactured with Cab70, whereas a residual loss of powder in the compact manufactured with LacBen gave the opposite indication. Such difference of sintering was confirmed by the mass variation which is consistent with TG data for Cab70, unlike LacBen. Nevertheless, high linear shrinkages (about $25 \%$ ) are recorded for both samples. A further rise of the temperature of the thermal treatment to $1100^{\circ} \mathrm{C}$ resulted in good sintering of the compact manufactured with LacBen and in partial melting of the compact manufactured with Cab70.

These considerations suggested to set the temperature of thermal treatments to $1050^{\circ} \mathrm{C}$ (compacts manufactured

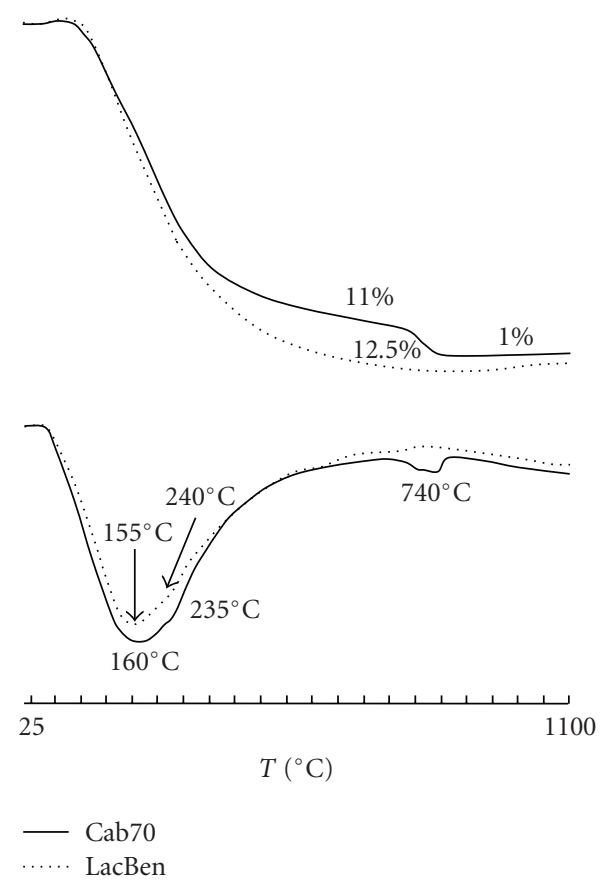

FIgURE 3: DTA and TG curves of Cab70 and LacBen powders.

with Cab70) and $1100^{\circ} \mathrm{C}$ (compacts manufactured with LacBen) and to further reduce the heating and the cooling rate according to what is reported in Table $3 \mathrm{~d}, 3 \mathrm{e}, 3 \mathrm{f}$, and 3g. Such experimental conditions appeared the most proper to thermally transform into ceramics Cab70 and LacBen powders evidencing good sintering, no fractures, and no melting in all the products of the different thermal treatments. Linear shrinkages remain quite high in absolute, although a marked reduction of their values (from about 2425 to $17-19 \%$ ) is recorded in the compacts having $h=3 \mathrm{~cm}$.

These same experimental conditions were used to perform the thermal treatments on the compacts manufactured with thermally treated powders $\left(600^{\circ} \mathrm{C} \mathrm{Cab70}\right.$ and $800^{\circ} \mathrm{C}$ LacBen) and on compacts manufactured with equal mass of thermally untreated and thermally treated powders $\left(600^{\circ} \mathrm{C}\right.$ Cab70 and $800^{\circ} \mathrm{C}$ LacBen). The thermal treatment of such compacts gives rise to lower mass variation (from $2 \%$ to 9\%) and linear shrinkages (about 16\%-17\%) than those recorded on homologous compacts manufactured entirely with thermally untreated Cab70 and LacBen, ceteris paribus.

The values of bulk density, apparent density, and porosity of compacts manufactured according to the treatments summarised in Table if and $1 \mathrm{~g}$, are reported in Table 5, whereas their most meaningful micrographs are reported in Figure 4. The results of such characterization procedures show moderately good and excellent densification of compacts manufactured with Cab70 and LacBen, respectively.

The average values of compressive strength of compacts manufactured with Cab70 and LacBen according to thermal treatments summarised in Table $1 \mathrm{f}$ and $1 \mathrm{~g}$ are $96.0 \pm 6.5 \mathrm{MPa}$ and $82.1 \pm 12.3 \mathrm{MPa}$, respectively, whereas their average values of Rockwell hardness are $94.2 \pm 0.8$ and $83.7 \pm 1.7$ HR30T, respectively. The Rockwell hardness of the stoneware 
TABle 5: Bulk density $\left(d_{b}, \mathrm{~g} / \mathrm{cm}^{3}\right)$, apparent density $\left(d_{a}, \mathrm{~g} / \mathrm{cm}^{3}\right)$, and porosity $(p, \%)$ of compacts manufactured with Cab70 and LacBen according to the thermal treatments summarised in Table $1 \mathrm{f}$ and $1 \mathrm{~g}$.

\begin{tabular}{lcccccc}
\hline & & Cab70 & \multicolumn{3}{c}{ LacBen } \\
& $d_{b}$ & $d_{a}$ & $p$ & $d_{b}$ & $d_{a}$ & $p$ \\
\hline Compact 1 & 2.38 & 2.54 & 6.02 & 2.21 & 2.22 & 0.26 \\
Compact 2 & 2.38 & 2.55 & 6.05 & 2.22 & 2.23 & 0.34 \\
Compact 3 & 2.38 & 2.56 & 7.04 & 2.23 & 2.24 & 0.56 \\
Compact 4 & & & & 2.23 & 2.25 & 0.56 \\
\hline
\end{tabular}

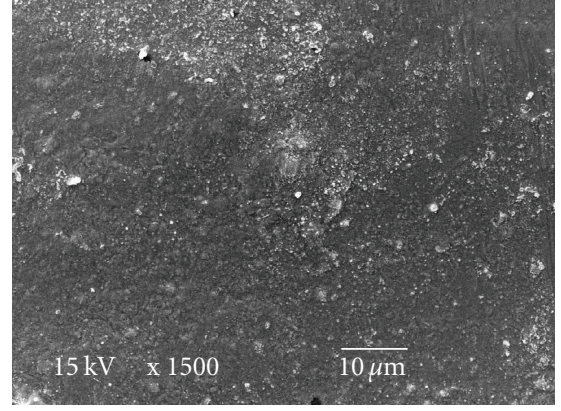

(a)

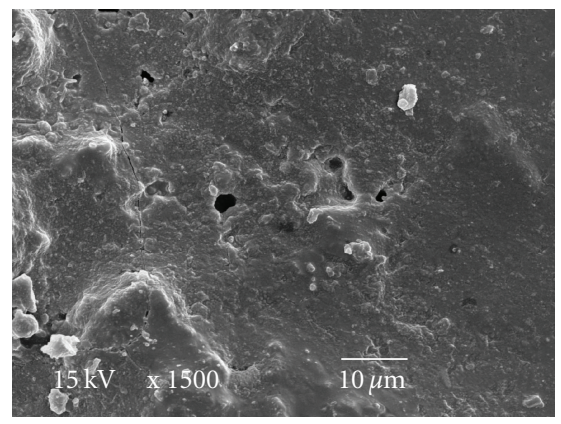

(c)

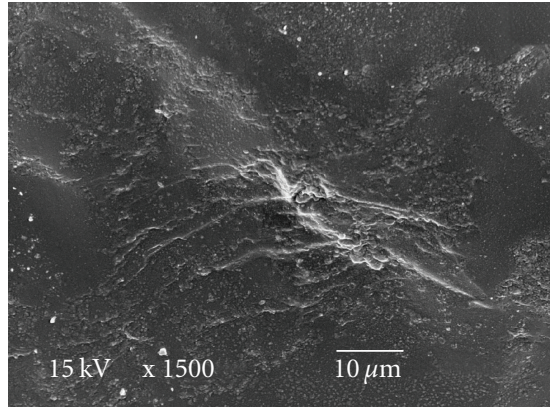

(b)

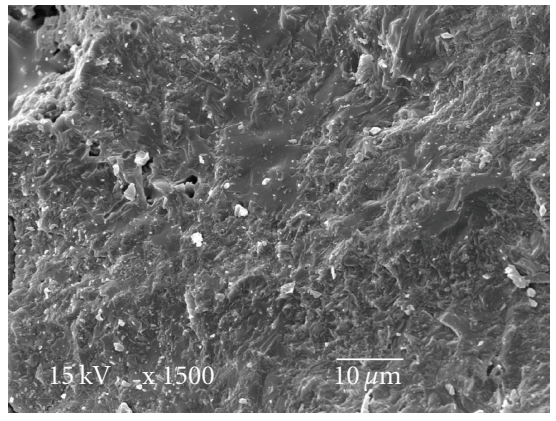

(d)

FIGURE 4: SEM micrographs: (a) External surface of the compact manufactured with LacBen according to the thermal treatment summarised in Table 1g, (b) internal surface of the same compact, (c) External surface of the compact manufactured with Cab70 according to the thermal treatment summarised in Table 1f, (d) internal surface of the same compact.

manufactured according to what is reported in experimental is $77.3 \pm 0.3 \mathrm{HR} 30 \mathrm{~T}[12]$.

\section{Discussion}

The experiments performed in this paper made it possible to collect some very positive indications concerning the possibilities of thermally transforming powder-like wastes of sawing of volcanic tuffs into ceramics, but also evidenced some difficulties and problems which require further reflections.

As far as positive indications are concerned, it must be remarked that the final products of the structural evolution of Cab70 and LacBen upon raising temperature do not largely differ from those of traditional ceramics. Actually, thermally treating Cab70 and LacBen at temperatures higher than $1000^{\circ} \mathrm{C}$ results in the thermal collapse of the structure of the zeolitic components of starting materials which gives rise to prevailingly amorphous products. Scant crystals of phases exhibiting high thermal stability, such as feldspar, augite, and quartz, are dispersed in such amorphous matrix which is mostly composed of silica, alumina, and iron oxide.

Another very positive indication is derived from the good ability of Cab70 and LacBen to give rise to very dense and compact final products. It could be said that data reported in Table 5 and micrographs reported in Figure 4 show an excellent densification of compacts manufactured with LacBen (Figure 4(a)) and an only moderately good densification of compacts manufactured with Cab70 (Figure 4(c)). This is even more evident by the aspect of the internal surfaces (Figures 4(b) and 4(d)). Nevertheless, the differences recorded in the densification of compacts manufactured with LacBen and Cab70 arise from the fact that the most proper temperature of the treatment $\left(1100^{\circ} \mathrm{C}\right)$ was set for the former, whereas the same could not be said for the latter. Actually, it appears likely that a temperature of thermal 
treatment ten-twenty degrees higher than $1050^{\circ} \mathrm{C}$ would improve densification and would avoid the beginning of melting which was found to occur at about $1100^{\circ} \mathrm{C}$.

Final positive indications may be found in the aesthetic and mechanical properties of compacts thermally treated according to what is reported in Table 1f and 1g. Actually, their appearance and in particular their brown-reddish colour, derived from the oxidation of iron oxides, strongly resembles the one typical of traditional ceramics fired at temperatures higher than $1000^{\circ} \mathrm{C}$. Even the mechanical properties are excellent as compressive strengths and Rockwell hardness appear very high in absolute thus suggesting the use of these ceramics as floors.

Together with these positive indications this paper has evidenced even problems and difficulties. Actually the thermal treatments of compacts manufactured with Cab70 and LacBen summarised in Table $1 \mathrm{~b}$ and $1 \mathrm{c}$ gave rise to products characterised by the presence of fractures parallel to the axe of the cylindrical compacts, sited along their lateral surface. The presence of such fractures may be substantially ascribed to the following phenomena.

(1) Thermal treatment of zeolite-bearing materials such as Cab70 and LacBen results in the evolution of zeolitic water. The presence of such zeolitic water (about 11-13 weight \%) makes these materials humid at room temperature and thus avoid the addition of water as temporary binder in manufacturing the green compact. Nevertheless, the presence of this water may create fractures in the final products as preferential paths through which evolve.

(2) The evolution of zeolitic water after thermal treatments is followed by the framework collapse of the zeolites with consequent loss of their microporosity. These phenomena give rise to marked shrinkage of the final products. The extent to which such shrinkage occurs is further explained by the fact that the density of the system has to increase from that typical of zeolitized tuffs (about $1,2 \mathrm{~kg} / \mathrm{cm}^{3}$ ) to the density of a final ceramic phase (about $3.0 \mathrm{~kg} / \mathrm{cm}^{3}$ ).

The approach followed in tackling these phenomena mainly consisted of slowing dramatically both the heating and the cooling rate so as to allow longer times to evolve zeolitic water and to release thermal stresses. This approach appeared substantially valid in as much as the heating and cooling modalities described in Table 1d, 1e, $1 \mathrm{f}, 1 \mathrm{~g}, 1 \mathrm{~h}, 1 \mathrm{i}, 1 \mathrm{l}$, and $1 \mathrm{~m}$ avoided the occurrence of the fractures.

Another problem arising in the thermal transformation of compacts manufactured with Cab70 and LacBen into ceramics is the high linear shrinkages: about $25 \%$ for compacts of $h=1.00 \mathrm{~cm}$ and about $17 \%-19 \%$ for compacts of $h$ $=3.00 \mathrm{~m}$. This discrepancy of values, which were computed measuring the diameter of compacts before and after firing, might be ascribed to the different heights of the two groups of compacts. Actually, it appears likely that the same thermal treatment results in the same percent volume reduction of the two groups of compacts. Such percent volume reduction occurs with a lower percent linear shrinkage of the diameter in the higher compact $(h=3.00 \mathrm{~cm})$ than in the lower $(h=$ $1.00 \mathrm{~cm}$ ). An attempt for obtaining lower linear shrinkages was performed by thermally treating the Cab70 and LacBen powders prior to manufacture compacts. Such preventive thermal treatment aimed at evolving part of zeolitic water and shrinking the grains of powder prior to manufacture compacts so as to give rise to lower mass variations and linear shrinkages of final products. This procedure allowed the reduction of such parameters (to $2 \%-9 \%$ and $16 \%-17 \%$, resp.) but not to the hoped extent.

\section{Conclusions}

The aim of the long-term study which begins with this paper was to evaluate the possibility of thermally transforming the powder-like waste of building and ornamental stones into ceramics. In particular, this paper investigated the thermal transformation of powders of volcanic tuffs that are used as building stones. Most of the results of this paper seem to supply positive indications. Actually, the structural evolution which brings products similar to traditional ceramics, the good ability to give rise to dense and compact final products, and the good mechanical properties and the lovely appearance agree in indicating the transformation of such powder-like waste in ceramics as a profitable and feasible recycle strategy. It should also be said that further beneficial consequences might arise from practically realising the proposed procedure. Actually, the thermal treatment of these powders at high temperatures would result in the combustion of the hydrocarbons coming from lubricating oils of gears of saws and in the solidification of the particles of heavy metals coming from the blades of the saws, thus finding a solution to these environmental problems.

Nevertheless, the high values of linear shrinkages recorded in this paper seem to strongly hinder the thermal transformation of powder-like waste from sawing of volcanic tuff in ceramics. Thus, this paper seems to suggest the continuity of the long-term study concerning the thermal transformation of powder-like waste from sawing of building and ornamental stones adding to volcanic tuffs a material characterised by a higher dimensional stability. Powder-like wastes derived from sawing of granites seem to meet the previous requirement as their main mineralogical components are phases such as feldspars and quartz which exhibit good thermal stability. Thus, the study of the thermal transformations of mixtures of volcanic tuffs, waste from sawing of building stones and granites, and waste from sawing of ornamental stones will be the subject of a forthcoming paper.

\section{Acknowledgments}

This paper was carried out with the financial support of the PRIN MIUR 2005 granted to Alessio Langella. The authors would like to thank G. Cerri for providing LacBen samples and IZ Company which provided Cab70 samples. 


\section{References}

[1] G. Blanco, Le Pietre Ornamentali in Architettura, La Nuova Italia Scientifica , 1995.

[2] D. Calcaterra, A. Langella, R. de Gennaro, M. de' Gennaro, and P. Cappelletti, "Piperno from Campi Flegrei: a relevant stone in the historical and monumental heritage of Naples," Environmental Geology, vol. 47, no. 3, pp. 341-352, 2005.

[3] L. Carta, D. Calcaterra, P. Cappelletti, A. Langella, and M. de'Gennaro, "The stone materials in the historical architecture of the ancient center of Sassari: distribution and state of conservation," Journal of Cultural Heritage, vol. 6, no. 3, pp. 277-286, 2005.

[4] C. Colella, M de' Gennaro, and R. Aiello, "Use of zeolitic tuff in the building industry," in Reviews in Mineralogy of Geochemistry-Natural Zeolites: Occurrence, Properties, Applications, D. L. Bish and D. W. Ming, Eds., pp. 551-587, Mineralogical Society of America, Blacksburg, Va, USA, 2001.

[5] M. de' Gennaro, D. Calcaterra, P. Cappelletti, A. Langella, and V. Morra, "Building stone and related weathering in the architecture of the ancient city of Naples," Journal of Cultural Heritage, vol. 1, no. 4, pp. 399-414, 2000.

[6] R. de Gennaro, D. Calcaterra, P. Di Girolamo, A. Langella, and M. de' Gennaro, "Discovering the stone heritage of southern Italy: technical properties of the Mondragone marble from Campania region," Environmental Geology, vol. 44, no. 3, pp. 266-276, 2003.

[7] P. Primavori, Pianeta Pietra, Zusi, Italy, 1999.

[8] IMM, “Studi e statistiche," 2007, http://www.immcarrara.com/ stat/.

[9] AA. VV., "Abstracts of the Symposium "Valorizzazione dei Fanghi Derivanti dalla Lavorazione Lapidea"," Domodossola, Italy, p. 16, 2005.

[10] M. de' Gennaro and P. Marone, "Alta formazione e ricerca in tema di utilizzo degli scarti dell'industria lapidea," in Atti del Convegno di Presentazione dei Risultati del Progetto Internazionale, Napoli, Italy, December 2006.

[11] R. de' Gennaro, P. Cappelletti, G. Cerri et al., "Influence of zeolites on the sintering and technological properties of porcelain stoneware tiles," Journal of the European Ceramic Society, vol. 23, no. 13, pp. 2237-2245, 2003.

[12] R. de Gennaro, M. Dondi, P. Cappelletti et al., "Zeolitefeldspar epiclastic rocks as flux in ceramic tile manufacturing," Microporous and Mesoporous Materials, vol. 105, no. 3, pp. 273-278, 2007.

[13] P. Cappelletti, G. Cerri, A. Colella et al., "Post-eruptive processes in the Campanian Ignimbrite," Mineralogy and Petrology, vol. 79, no. 1-2, pp. 79-97, 2003.

[14] B. De Vivo, G. Rolandi, P. B. Gans et al., "New constraints on the pyroclastic eruptive history of the Campanian volcanic Plain," Mineralogy and Petrology, vol. 73, no. 1-3, pp. 47-65, 2001.

[15] A. Perrotta and C. Scarpati, "Plinian versus co-ignimbrite volume in large explosive eruptions: the example of the Campanian Ignimbrite eruption," Mineralogy and Petrology, vol. 79, no. 1-2, pp. 67-78, 2003.

[16] G. Cerri, Caratterizzazione mineralogica e tecnologica dei tufi zeolitizzati della Sardegna settentrionale, Ph.D. thesis, University of Sassari, Sassari, Italy, 2000.

[17] G. Cerri, P. Cappelletti, A. Langella, and M. de'Gennaro, "Zeolitization of oligo-miocene volcaniclastic rocks from Logudoro," Contributions to Mineralogy and Petrology, vol. 140, no. 4, pp. 404-421, 2001.
[18] L. Melluso, V. Morra, P. Brotzu et al., "Geochronology and petrogenesis of the cretaceous Antampombato-Ambatovy complex and associated dyke swarm, Madagascar," Journal of Petrology, vol. 46, no. 10, pp. 1963-1996, 2005.

[19] S. J. Chipera and D. L. Bish, "Multireflection RIR and intensity normalizations for quantitative analyses: applications to feldspar and zeolites," Powder Diffraction, vol. 10, pp. 47-55, 1995.

[20] S. D'Auria, Impiego di materiali zeolitizzati per la produzione di prodotti ceramici, Ph.D. thesis, Federico II University, Napoli, Italy, 2006, Tutor Prof. M. de'Gennaro.

[21] M. de' Gennaro, C. Colella, E. Franco, and R. Aiello, "Italian zeolites 1. Mineralogical and technical features of Neapolitan yellow tuff," Industrial Minerals, vol. 186, pp. 47-53, 1983.

[22] M. de' Gennaro, C. Colella, R. Aiello, and E. Franco, "Italian zeolites 2. Mineralogical and technical features of Campanian tuff," Industrial Minerals, no. 204, pp. 97-109, 1984.

[23] A. Colantuono, S. Dal Vecchio, G. Mascolo, and M. Pansini, "Dilatometric behaviour of chabazite," Journal of Thermal Analysis, vol. 47, no. 1, pp. 281-289, 1996.

[24] A. Langella, M. Pansini, G. Cerri, P. Cappelletti, and M. de'Gennaro, "Thermal behavior of natural and cationexchanged clinoptilolite from Sardinia," Clays and Clay Minerals, vol. 51, no. 6, pp. 625-633, 2003.

[25] G. Dell'Agli, C. Ferone, G. Mascolo, and M. Pansini, "Dilatometry of Na-, K-, Ca- and $\mathrm{NH}_{4}$-clinoptilolite," Thermochimica Acta, vol. 336, no. 1-2, pp. 105-110, 1999.

[26] G Dell'Agli, C. Ferone, G. Mascolo, and M. Pansini, "Dilatometric characterization of natural phillipsite and chabazite bearing materials," in Natural Zeolites for the Third Millennium, C. Colella and F. A. Mumpton, Eds., pp. 299-304, De Frede, Napoli, Italy, 2000. 

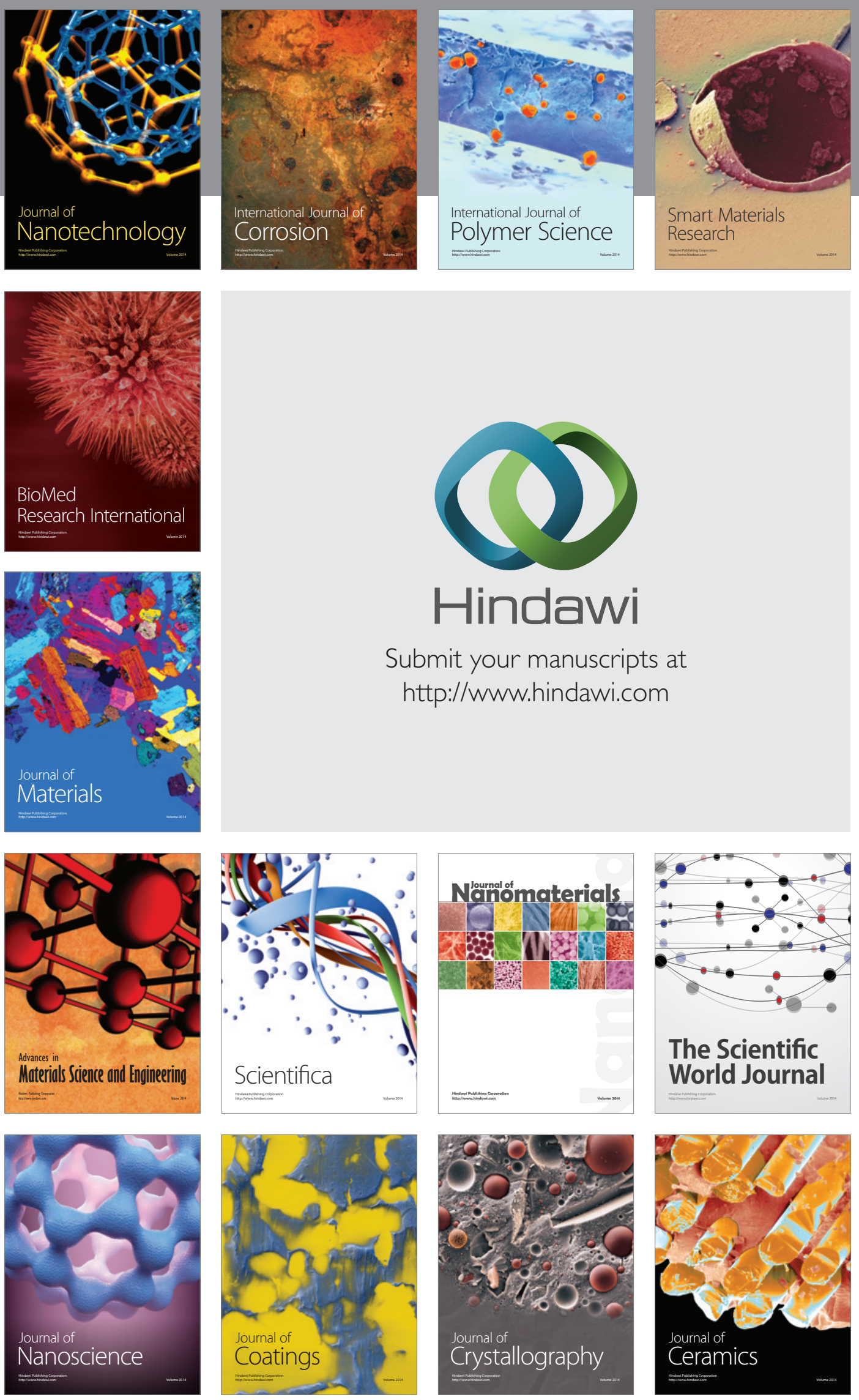

The Scientific World Journal

Submit your manuscripts at

http://www.hindawi.com

\section{World Journal}

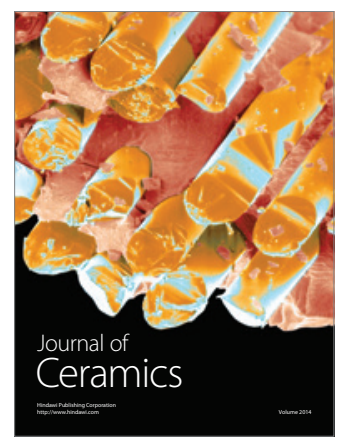

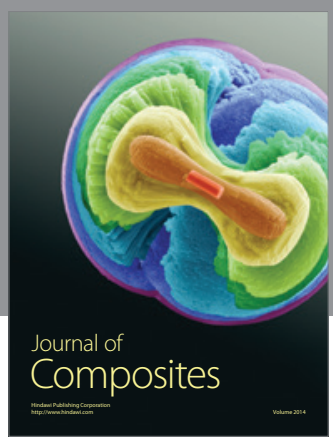
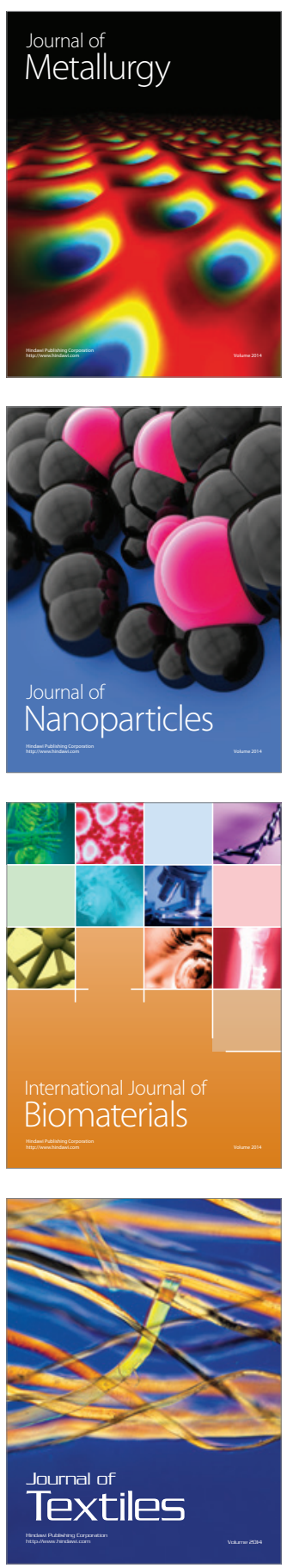